\title{
Thinking in paracoccidioidomycosis: a delayed diagnosis of a neglected tropical disease, case report and review of clinical reports and eco-epidemiologic data from Colombia since the 2000
}

\author{
Deving Arias Ramos ${ }^{1,2^{*}}$ (D), John Alexander Alzate ${ }^{2,3}$ (D), Ángela María Giraldo Montoya ${ }^{1,2,4}$, \\ Yessica Andrea Trujillo ${ }^{1}$ and Leidy Yurany Arias Ramos ${ }^{1}$
}

\begin{abstract}
Background: Paracoccidioidomycosis is a neglected tropical disease, endemic in several countries of South America including Colombia. We report a case of a patient with Chronic Multifocal Paracoccidioidomycosis with long-standing symptoms and a delayed diagnosis caused by several barriers to achieve it. We did a review of the papers published in Colombia about this disease, focusing in clinical data and eco-epidemiology with the finding of a lack of new information on this topic since the 2000 in our region.

Case presentation: We present a 54-year-old man, farmer in his youth, with a chronic ulcerated lesion in the lower lip similar to a lip carcinoma, a deforming lesion in the nose, and respiratory symptoms with emphysematous lung. Lip biopsy with silver methenamine stain revealed small and large budding yeasts that resembles a "mariner's wheel" confirming Chronic Multifocal Paracoccidioidomycosis. He was treated successfully but subsequently lost to follow up.

Conclusions: It is very important to focus attention, reinforce the search and create networks for the study of neglected tropical diseases. The presented case illustrates a usual clinical presentation, but with a delayed diagnosis due to the difficulties that still occur in some regions like ours for the early recognition of a case of chronic multifocal paracoccidioidomycosis.
\end{abstract}

Keywords: Paracoccidioidomycosis, Neglected tropical disease, Colombia, Pulmonary emphysema, Oral Cancer

\section{Background}

Paracoccidioidomycosis (PCM) is a granulomatous systemic mycosis, endemic in South America from Mexico to Argentina, with the largest number of cases reported in Brazil, Venezuela, Colombia and Argentina [1-4]. It is caused by a fungus of the genus Paracoccidioides that has a dimorphic behavior. It has been isolated in the nine-banded armadillo (Dasypus novemcinctus) [5], the

\footnotetext{
* Correspondence: deving.arias@gmail.com

${ }^{1}$ Universidad Tecnológica de Pereira, Pereira, Colombia

${ }^{2}$ Grupo de Investigación en Medicina Interna, Universidad Tecnológica de

Pereira, Pereira, Colombia

Full list of author information is available at the end of the article
}

naked-tailed armadillo (Cabassus centralis), domestic animals, cattle, horses, sheep and monkeys [3, 6, 7]. In Colombia it is not a disease of obligatory notification and therefore its incidence and prevalence is not known with certainty.

Paracoccidioidomycosis is considered a neglected tropical disease [8]. We present a case of PCM from a region of Colombia with the objective of maintaining attention to a forgotten tropical disease with a usual clinical presentation but with a delayed diagnosis. The case reviewed illustrates the difficulties still present for the diagnosis of PCM in some regions like ours and the lack of awareness in the medical community for this type of disease. 


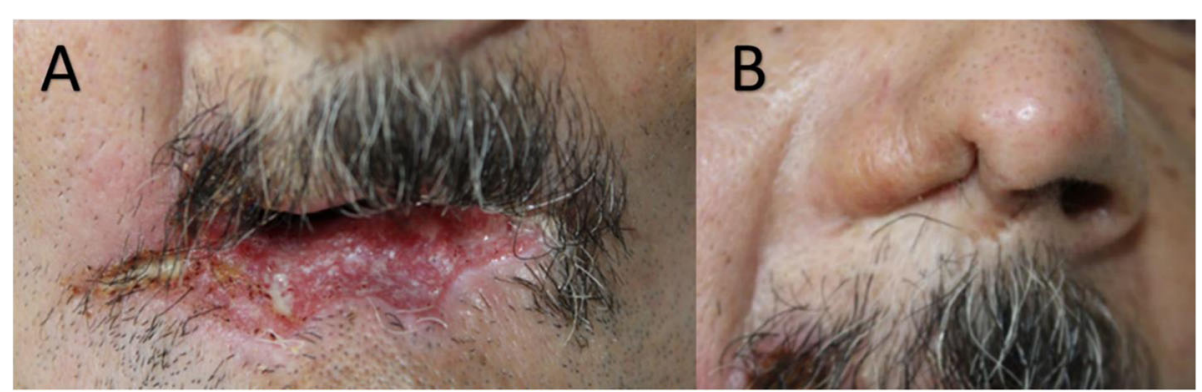

Fig. 1 a Deforming and infiltrating ulcer in lower lip. b Deformity in the right nasal wing

\section{Case presentation}

A 54-year-old man from rural area of the department of Risaralda (Colombia), with a history of 3 years of a papule-like lesion in the lower lip that increased in size and then evolved to a deforming ulcer with extension towards the right labial commissure (Fig. 1). He presented a progressive deformity in the right nasal wing (Fig. 1), spontaneous loss of teeth, weight loss of $15 \mathrm{Kg}$, dry cough and dyspnea, without other B symptoms. He was a former smoker with a pack-year of 1.5 for 10 years and was receiving Metformin for a recent diagnosis of type 2 Diabetes Mellitus. He was a coffee farmer in his youth and then worked as a butcher for 30 years. Interestingly, we find that in his youth he had the habit of consuming armadillo meat and blood. He had several medical consultations, with difficulties for the follow-up caused by social aspects. A presumptive diagnosis of lip cancer was made for which a biopsy was performed.

An incisional biopsy of the lip showed pseudoepitheliomatous hyperplasia associated with suppurative granulomatous dermatitis, the silver methenamine stain revealed budding yeasts that resembles a "mariner's wheel" confirming the diagnosis of Chronic Multifocal Paracoccidioidomycosis (Fig. 2). A Chest X-ray and then a HR-CT revealed emphysematous lung disease (Fig. 3), a HIV test and a VDRL were negative. A nasofiberoptic bronchoscopy was performed to rule out tuberculosis; during the study there was seen granulomatous lesions in upper airway and other ulcerated lesions covered by punctiform white secretion (Fig. 4). There was no presence of fungal structures in the routine stains of the bronchoalveolar lavage. The culture for fungal and Mycobacterial was negative, as so the PCR for Mycobacterium tuberculosis.

Due to the severe constitutional commitment, he received amphotericin B for 7 days and then we made a change for Itraconazole $200 \mathrm{mg}$ QD for 12 months, with successful recovery, but then lost the follow-up.

\section{Discussion and conclusions}

Paracoccidioidomycosis can manifest in an acute/subacute form in young patients or in a chronic form

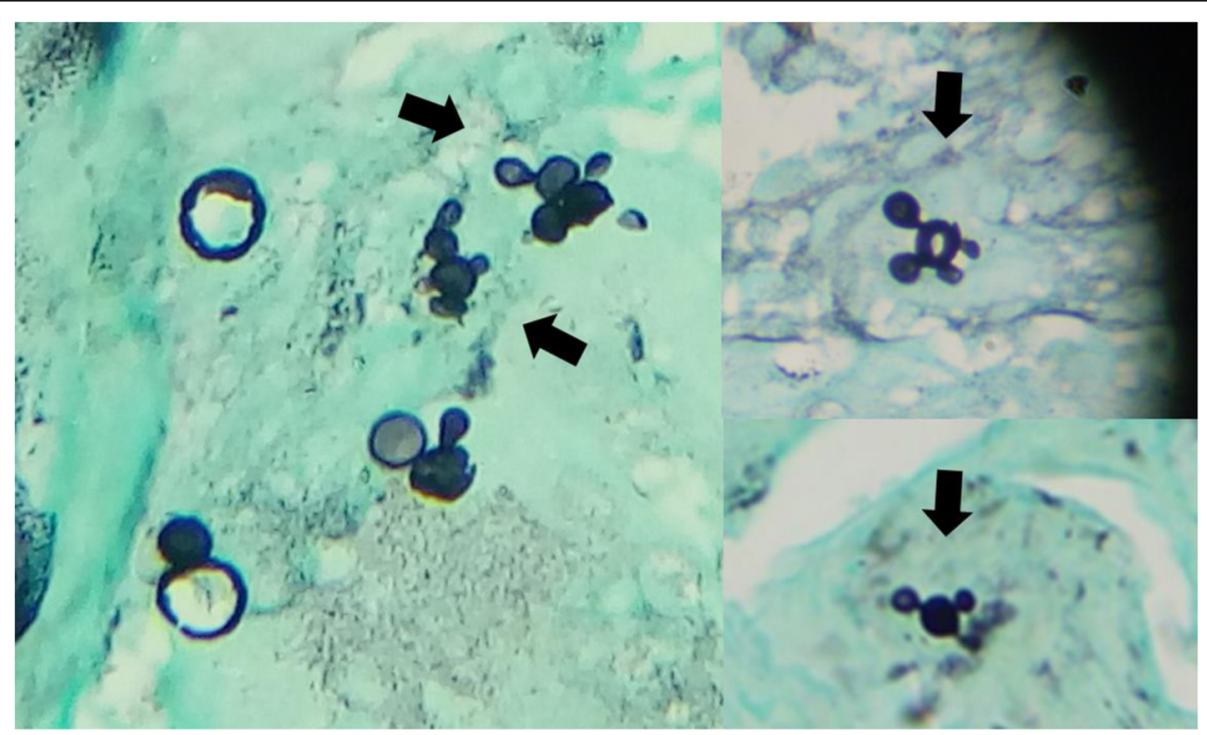

Fig. 2 Silver methenamine stain. Budding yeasts that resembles a "mariner's wheel" 


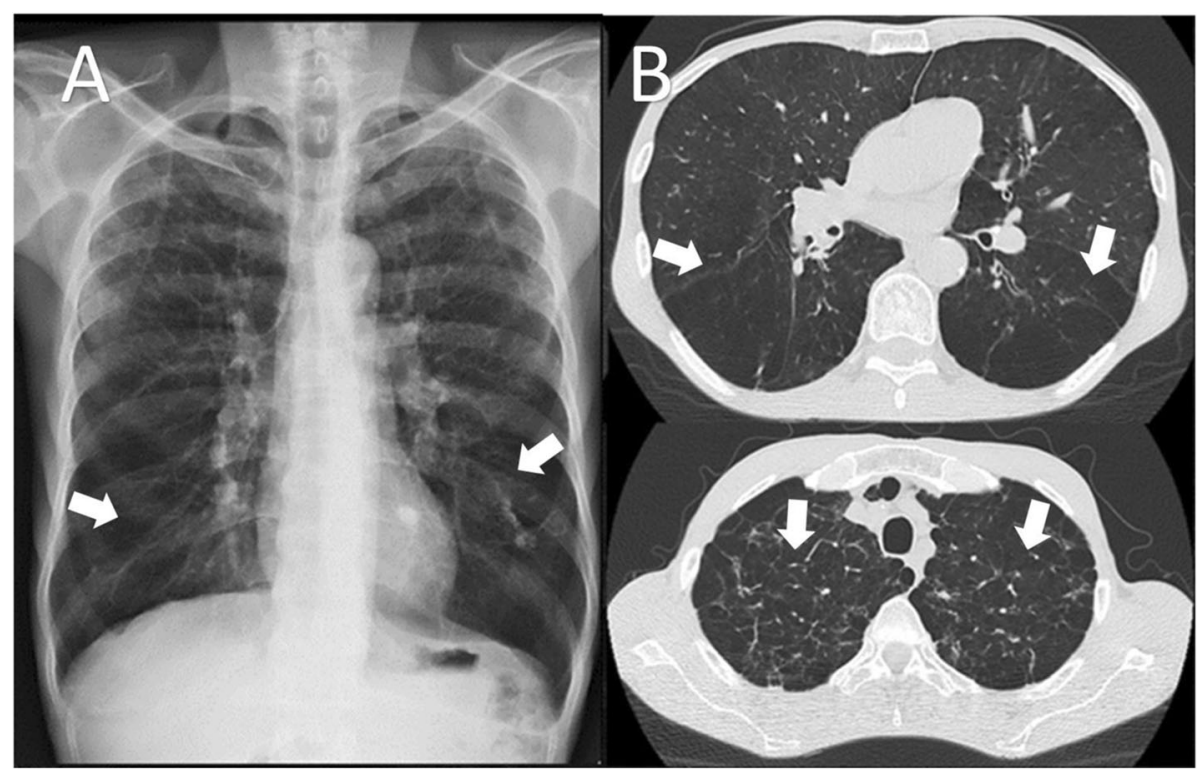

Fig. 3 a Chest $x$-ray showing interstitial opacities and fibrotic tracts in the lung bases. $\mathbf{b}$ High Resolution Tomography of the chest. Lung window showing centrilobular and paraseptal emphysematous foci

mainly in adults. The chronic form is more frequent and has an age of presentation between 30 and 60 years due to a prolonged incubation period, with multifocal compromise, mostly respiratory and mucocutaneous [8-10].. Given its heterogeneous nature, this disease is considered a "great imitator" and can be a diagnostic challenge in areas of low endemicity $[11,12]$. The differential diagnosis of mucocutaneous commitment includes another tropical diseases like mucocutaneous Leishmaniasis, Sporotrichosis and Histoplasmosis; other conditions like squamous cell carcinoma, non-Hodgkin's T/Nk cell lymphoma and vasculitis should be considered [13, 14]. In the case presented, it is noteworthy that pulmonary involvement was mainly emphysematous with formation of bullae and fibrotic tracts that are associated with residual forms of this condition. The differential diagnosis is with secular forms of Tuberculosis and Histoplasmosis, and it is hardly explained by the low smoke exposure of this patient; to achieve the clinical diagnosis, the clinician can be guided if there is a concomitant presence of mucocutaneous lesions and adenopathies forming a triad of characteristic symptoms of this disease $[12,15]$.

Paracoccidioidomycosis is considered a neglected tropical disease [16]. Of note, in Colombia, most of the information on the eco-epidemiology of the disease comes from publication until 2000, which allowed estimating the incidence and prevalence of the disease. To mention, the prevalence is 32.4 cases/year (period 1970-1999) [17] and the incidence rate is $0.1-2.4$ cases/1.000.000 inhabitants per year [18]. We also know that there is a variation in the incidence according to the geographical area, and this is caused by certain ecological characteristics such as altitudes between 1000 to $1499 \mathrm{~m}$ above sea level, coffee plantations and rainfall between 2000 and $2999 \mathrm{~mm} /$ year [1]. All these estimates have serious limitations, mainly because this disease is not for mandatory

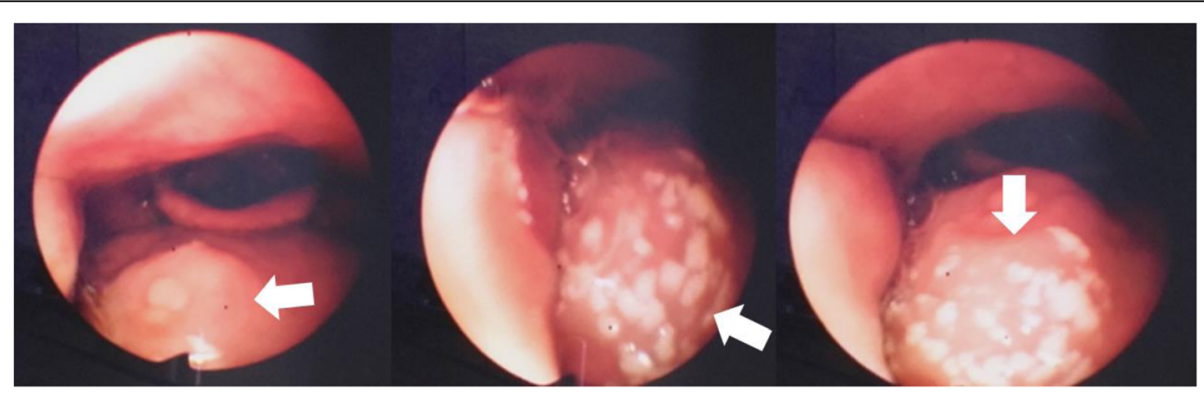

Fig. 4 Nasofiberoptic bronchoscopy. Granulomatous lesions and ulcerated lesions covered with punctiform white secretion in upper airway 
notification to the health system, so there are no reliable sources of information even in the current days.

To know about the current state of the disease in Colombia we look for publications since 2000 focusing on eco-epidemiology and clinical information. We did a search with the words "Paracoccidioidomycosis" "Paracoccidioides" and "Colombia" on PUBMED, BIREME (a Latin American and Caribbean Center for Information in Health Sciences), an several representative journals of Colombia: Biomédica (Journal of the National Institute of health, e-ISSN: 01204157), Case Reports (Journal of the Universidad Nacional, e-
ISSN: 2462-8522), CES MEDICINA (Journal of Universidad CES, e-ISSN 2215-9177), Revista Médica de Risaralda (Journal of Faculty of Universidad Tecnológica de Pereira, ISSN: 2539-5203), Colombia Médica (Journal of the Universidad del Valle, ISSN-1657-9534), Medicina U.P.B (Journal of the Universidad Pontificia Bolivariana, e- ISSN: 2357-6308), IATREIA and Hechos Microbiológicos (Journals of Universidad de Antioquia, e-ISSN 2011-7965 and ISSN:2145-8898 respectively). The findings are resume in Table 1 . Of note, there is no any information about possible changes in ecoepidemiology given the development of some geographic

Table 1 Papers on clinical and eco-epidemiology of paracoccidioidomycosis in Colombia since 2000

\begin{tabular}{lll}
\hline Year Type of paper & Details of the study, Clinical and epidemiological characteristics & Ref \\
\hline 2000 Case report & $\begin{array}{l}\text { A 24year-old male farmer with an enlarging mass in the right testicle, retroperitoneal and inguinal nodules, } \\
\text { pancreatic infiltration and hepatosplenomegaly due to juvenile PCM. The patient was resident of the rural area of the } \\
\text { municipality of Tarso, department of Antioquia. }\end{array}$
\end{tabular}

2000 Case report

A 55 year-old male with Multifocal PCM, who presented with neurological symptoms and an ulcerated granulomatous lesion in the abdomen. The patient lived in the city of Medellín, department of Antioquia, but in his younger years, was a farmer in a rural region.

2002 Case series

Six patients with adrenal insufficiency from a registry of 207 patients from the archives of the Corporación para Investigaciones Biológicas (CIB), in Medellín, department of Antioquia. Average age 67.2 years, they were residents of rural area, five of them were farmers and smokers.

2003 Case series Follow-up for pulmonary abnormalities in 47 itraconazole-treated patients with PCM. Fibrosis was observed in 31.8\% of the patients at diagnosis and developed de novo in $25 \%$ of the patients.

2005 Phylogenetic Study

Determination of at least three distinct species of PCM: S1, PS2, and PS3 (apparently restricted to regions of Colombia).

2005 Ecological study First report of P. brasiliensis isolation from the spleen of a naked-tailed armadillo Cabassous centralis captured in a coffee farm localized in a Colombian endemic area for PCM.

2007 Case report Autopsy diagnosis of a 63-year-old man patient, resident of the rural area of the municipality of Lebrija, department of Santander, with pulmonary, lymphatic and adrenal PCM.

2008 Retrospective cohort study

63 patients diagnosed and treated between 1978 and 2005 in the city of Medellín. 65.1\% had mucosal lesions, 38.1\% had Odynophagia and dysphagia, all patients had lung interstitial infiltrates and fibrosis was recorded in $46 \%$.

20092 cases Report of two cases of adrenal insufficiency secondary to infiltration of the adrenal glands. The case 2 lived in the city of Medellín, but with a history of previous residence in Venezuela

2010 Cross-sectional Evaluation of the status of the adrenal gland function after completion of antifungal therapy of patients with PCM study: 28 patients. who had been treated earlier at the CIB: 7.1\% showed adrenal insufficiency. Average age 55.3 years, all were male patients, $39.3 \%$ were farmers and $85.7 \%$ were smokers, $60.7 \%$ had chronic multifocal form, $21.4 \%$ had sub-acute form, and $17.9 \%$ had the chronic unifocal form.

2010 Case report

A 31-year-old HIV infected male patient, Embera Catío indigenous, resident of rural area of the municipality of Tarazá (department of Antioquia), works as a coca leaf scraper and with a history of smoking; presenting with simultaneous co-infection by Histoplasma capsulatum and Paracoccidioides brasiliensis.

2011 Case report 56-year-old male with Multifocal chronic PCM, residing in an urban area of the city of Cali (department of Valle del Cauca): he had emigrated from a wooded region of the city of Pasto (department of Nariño) where he performed agricultural and carpentry tasks.

2011 Case series A descriptive case series study aimed at determining the type and frequency of opportunistic diseases in HIV/AIDS patients: 1 case with co-infection by P. brasiliensis.

2014 Case report A 12-year-old woman with disseminated juvenile PCM diagnosed in an urban area of Bogotá, Colombia.

2015 Case report A 69-year-old HIV infected male patient with a CD4 T-cell count of 23 cells/mL, presenting with Cutaneous PCM. He was a farmer in a rural area of the department of Antioquia.

2016 Case report A 10-year-old man from the rural area of the municipality of Yotoco, department of Valle del Cauca, presenting with subacute lymphatic PCM.

2017 Case report 67-year-old male with pulmonary PCM, resident of the rural area of the municipality of Aratoca, department of Santander, worked as a farmer, with a history of smoking.

2018 Case report 49-year-old male, coffee grower, from City of Acevedo, department of Huila, with a history of smoking, presenting with Multifocal chronic PCM. 
areas of the country and transition phenomena caused by the population movements from rural to urban areas for violence, and vice versa given the transition to peace since the end of the war; in addition, we do not have information on possible imported cases caused by migratory movements in recent years from Venezuela, a country endemic to this disease, and this, of course, is a challenge considering the long latent period of this disease that would force us to seek the implementation of screening tests for migrants.

The lack of new information in the last two decades on the eco-epidemiology and the clinical and social characterization of patients with Paracoccidioidomycosis reaffirms it as a neglected tropical disease, an aggravated situation during the last two decades despite the era of informatics, and also it is a call for physicians, institutions, and government to start working on this issue again. The main problems to recognize PCM seem to be 1) the apparent rare occurrence of the disease; 2) the difficulty to diagnose the disease in a timely manner; 3 ) the lack of interest of the clinicians to make it more visible, from the instances of the health system to the instances of medical education at the individual level. From this perspective, it seems that the way to begin to solve this problem could be to create a national network that involves leaders in the different medical schools.

\section{Abbreviations}

BAL: Bronchoalveolar lavage; BMI: Body mass index; HIV: Human Immunodeficiency Virus; HR-CT: High-resolution Computed Tomography; Kg: Kilogram; PCM: Paracoccidioidomycosis; PCR: Polymerase chain reaction; QD: "quaque die", which means, in Latin, once a day; T2DM: Type 2 Diabetes Mellitus; VDRL: Venereal Disease Research Laboratory

\section{Acknowledgments}

To the Instituto Liga Contra el Cáncer Seccional Pereira, Risaralda, where the initial assessment, biopsy and histochemistry were performed and allowed the diagnosis.

To the Hospital Universitario San Jorge de Pereira, Colombia, where the diagnosis and treatment of the patient was made.

\section{Authors' contributions}

DAR was the main responsible for the writing of the full article. JAA, AMGM and YAT analyzed and interpreted the patient data and made important contributions in the writing of the manuscript. LYAR contributed some ideas in the discussion and helped conduct several of the corrections requested in the peer review process. All authors read and approved the final manuscript.

\section{Funding}

The mentioned authors are not currently receiving and have not received any financial support for the development of the manuscript mentioned above. This research did not receive any specific grant from funding agencies in the public, commercial, or not-for-profit sectors.

\section{Availability of data and materials}

The datasets used and/or analysed during the current study available from the corresponding author on reasonable request.

\section{Ethics approval and consent to participate}

This article is of the case report type. We obtained informed consent from the patient to make the case report in accordance with the ethical responsibilities of the authors.

\section{Consent for publication}

We have obtained consent to publish from the participant to report individual patient data. Consent to publish was given in written format. The written consent for publication obtained from the patient was also inclusive of publishing identifying images.

\section{Competing interests}

The authors declare that they have no competing interests.

\section{Author details}

${ }^{1}$ Universidad Tecnológica de Pereira, Pereira, Colombia. ${ }^{2}$ Grupo de Investigación en Medicina Interna, Universidad Tecnológica de Pereira, Pereira, Colombia. ${ }^{3}$ Hospital Universitario San Jorge, Universidad Tecnológica de Pereira, Pereira, Colombia. ${ }^{4}$ Hospital Universitario San Jorge, Pereira, Colombia.

Received: 9 July 2019 Accepted: 6 February 2020

Published online: 10 February 2020

\section{References}

1. Calle D, Rosero DS, Orozco LC, Camargo D, Castañeda E, Restrepo A. Paracoccidioidomycosis in Colombia: an ecological study. Epidemiol Infect. 2001;126:309-15.

2. Alva ZB. Aspectos clínicos de la Blastomicosis sudamericana (Paracoccidioidomicosis) en el Perú. Rev Peru Med Exp Salud Publica. 2002;19:43-7.

3. Restrepo A, McEwen JG, Castañeda E. The habitat of Paracoccidioides brasiliensis: how far from solving the riddle? Med Mycol. 2001;39:233-41.

4. Martinez R. Epidemiology of Paracoccidioidomycosis. Rev Inst Med Trop Sao Paulo. 2015;57(Suppl 19):11-20 PubMed PMID: 26465364. Pubmed Central PMCID: PMC4711199. Epub 2015/10/16.

5. Corredor GG, Castaño JH, Peralta LA, Díez S, Arango M, McEwen J, Restrepo A. Isolation of Paracoccidioides brasiliensis from the nine-banded armadillo Dasypus novemcinctus, in an endemic area for paracoccidioidomycosis in Colombia. Rev Iberoam Micol. 1999;16:216-20.

6. de Farias MR, Condas LA, Ribeiro MG, Bosco Sde M, Muro MD, Werner J, et al. Paracoccidioidomycosis in a dog: case report of generalized lymphadenomegaly. Mycopathologia. 2011;172(2):147-52 PubMed PMID: 21424604. Epub 2011/03/23. eng.

7. Corte AC, Svoboda WK, Navarro IT, Freire RL, Malanski LS, Shiozawa MM et al. Paracoccidioidomycosis in wild monkeys from Parana state, Brazil. Mycopathologia. 2007;164(5):225-8 PubMed PMID: 17914662. Epub 2007/ 10/05. eng.

8. Bellissimo-Rodrigues F, Bollela VR, Da Fonseca BA, Martinez R. Endemic paracoccidioidomycosis: relationship between clinical presentation and patients' demographic features. Med Mycol. 2013;51(3):313-8 PubMed PMID: 22928923. Epub 2012/08/30.

9. Franco M, Montenegro MR, Mendes RP, Marques SA, Dillon NL, Mota NGDS. Paracoccidioidomycosis: a recently proposed classification of its clinical forms. Rev Soc Bras Med Trop. 1987;20:129-32.

10. de Freitas RMC, Prado R, do Prado FLS, de Paula IB, Figueiredo MTA, Ferreira CS, Goulart EMA, Pedroso ERP. Pulmonary paracoccidoidomycosis: radiology and clinical-epidemiological evaluation. Revista da Sociedade Brasileira de Medicina Tropical. 2010;43:651-6.

11. Ramirez-Olivencia G, Ramirez-Rubio O, Gonzalez PR, Herrero MD, Puente SP. Paracoccidioidomycosis in a Spanish missionary. J Travel Med. 2010;17(2): 139-40 PubMed PMID: 20412183. Epub 2010/04/24.

12. Manns BJ, Baylis BW, Urbanski SJ, Gibb AP, Rabin HR. Paracoccidioidomycosis: case report and review. Clin Infect Dis. 1996;23(5): 1026-32 PubMed PMID: 8922797. Epub 1996/11/01. eng.

13. Parker NP, Pearlman AN, Conley DB, Kern RC, Chandra RK. The dilemma of midline destructive lesions: a case series and diagnostic review. Am J Otolaryngol. 2010;31(2):104-9 PubMed PMID: 20015726.

14. Girardi FM, Scrofernecker ML. Oral paracoccidiodomycosis mimicking lip carcinoma. Braz J Infect Dis. 2016;20(1):103-4 PubMed PMID: 26626167. Epub 2015/12/03.

15. Costa AN, Benard G, Albuquerque AL, Fujita CL, Magri AS, Salge JM, et al. The lung in paracoccidioidomycosis: new insights into old problems. Clinics. 2013;68(4):441-8. 
16. Queiroz-Telles F, Fahal AH, Falci DR, Caceres DH, Chiller T, Pasqualotto AC. Neglected endemic mycoses. The Lancet Infectious Diseases. 2017;17(11): e367-e77.

17. Calle D, Rosero DS, Orozco LC, Camargo D, Castaneda E, Restrepo A. Paracoccidioidomycosis in Colombia: an ecological study. Epidemiol Infect 2001;126(2):309-15 PubMed PMID: 11349982. Pubmed Central PMCID: PMC2869696. Epub 2001/05/15. eng.

18. Torrado E, Castañeda E, de la Hoz F, Restrepo A. Paracoccidioidomicosis: definición de las áreas endémicas de Colombia. Biomédica. 2000;20:327-34.

19. Rosero DS, Calle Salazar D, Matute G, Tobón ÁM, Restrepo Á. El caso de infecciosas. Paracoccidioidomicosis. Presentación Inusual en un Paciente Joven. Medicina UPB. 2011;19(1):9 Epub 2011-09-30.

20. Villa LA, Tobon A, Restrepo A, Calle D, Rosero DS, Gomez BL, et al. Central nervous system paracoccidioidomycosis. Report of a case successfully treated with itraconazol. Rev Inst Med Trop Sao Paulo. 2000;42(4):231-4 PubMed PMID: 10968887. Epub 2000/09/01. eng

21. Onate JM, Tobon AM, Restrepo A. Adrenal gland insufficiency secondary to paracoccidioidomycosis. Biomedica. 2002;22(3):280-6 PubMed PMID 12404928. Epub 2002/10/31. Insuficiencia suprarrenal secundaria a paracoccidioidomicosis. spa.

22. Tobon AM, Agudelo CA, Osorio ML, Alvarez DL, Arango M, Cano LE, et al. Residual pulmonary abnormalities in adult patients with chronic paracoccidioidomycosis: prolonged follow-up after itraconazole therapy. Clin Infect. 2003;37(7):898-904 PubMed PMID: 13130400. Epub 2003/09/ 18. eng.

23. Matute DR, McEwen JG, Puccia R, Montes BA, San-Blas G, Bagagli E, et al. Cryptic speciation and recombination in the fungus Paracoccidioides brasiliensis as revealed by gene genealogies. Mol Biol Evol. 2006;23(1):65-73 PubMed PMID: 16151188. Epub 2005/09/10. eng.

24. Corredor GG, Peralta LA, Castano JH, Zuluaga JS, Henao B, Arango M, et al. The naked-tailed armadillo Cabassous centralis (miller 1899): a new host to Paracoccidioides brasiliensis. Molecular identification of the isolate. Med Mycol. 2005;43(3):275-80 PubMed PMID: 16010854

25. Hernández JCM, Africano AM, Guevara MC. Paracoccidioidomicosis diseminada con insuficiencia suprarrenal: reporte de un caso de autopsia. Revista Médicas UIS. 2007;21(3):97-105.

26. Restrepo A, Tobon AM, Agudelo CA, Ochoa JE, Rosero DS, Osorio ML, et al. Co-existence of integumentary lesions and lung $x$-ray abnormalities in patients with paracoccidioidomycosis (PCM). Am J Trop Med Hyg. 2008; 79(2):159-63 PubMed PMID: 18689616. Epub 2008/08/12. eng.

27. Agudelo CA, Munoz C, Ramirez A, Gutierrez J, Velez S, Perez JC, et al. Identification of Paracoccidioides brasiliensis in adrenal glands biopsies of two patients with paracoccidioidomycosis and adrenal insufficiency. Revista do Instituto de Medicina Tropical de Sao Paulo. 2009;51(1):45-8 PubMed PMID: 19229390. Epub 2009/02/21. eng.

28. Tobon AM, Agudelo CA, Restrepo CA, Villa CA, Quiceno W, Estrada S, et al. Adrenal function status in patients with paracoccidioidomycosis after prolonged post-therapy follow-up. Am J Trop Med Hyg. 2010;83(1):111-4 PubMed PMID: 20595488. Pubmed Central PMCID: 2912586.

29. Rodríguez AZ, Bustamante KA, Tobón Orozco ÁM, Gómez CDB, Cano Restrepo LE, Vélez LC, Arteaga MA, Moreno ÁR. Histoplasmosis y paracoccidioidomicosis progresivas diseminadas en un paciente con sida: presentación de un caso. Hechos Microbiológicos. 2010;1(2):57-64.

30. Zapata K, Villanueva J, Arrunátegui A, López JG. Case report: Multifocal chronic paracoccidioidomycosis in an adult; 2011.

31. Jiménez MÁC, Rey-Benito GJ, Beltrán SD, Pinilla Guevara CA, Pieruccini SB, Mahecha CMA, Moreno CAÁ. Diagnóstico de micosis oportunistas en pacientes con VIH/sida: un estudio de casos en Colombia. Infectio. 2011; 15(2):92-7.

32. Angélica B, Sandra B, Jaime P, Cynthia B, Rocío O. Paracoccidioidomicosis juvenil diseminada diagnosticada en una niña en área urbana. Biomédica. 2014;34(1):21-8.

33. Catano JC, Morales M. Cutaneous Paracoccidioidomycosis. Am J Trop Med Hyg. 2015;93(3):433-4 PubMed PMID: 26333727. Pubmed Central PMCID: 4559674.

34. Beltrán J, Arenas X, Torres L, Hurtado I, Medina EL, Sierra A, Ramirez MT, Valencia L, Lopez P. PARACOCCIDIOIDOMICOSIS SUBAGUDA GANGLIONAR PRESENTACIÓN DE UN CASO CLINICO EN PEDIATRIA. Grastrohnup. 2016; 17(3):S13-S6.

35. Quintero Alvarez FM, Garcia-Habeych JM, Baez Duarte JP, Montes Ortiz JP, Mendinueta Giacometto SA. Pulmonary paracoccidioidomycosis associated with septic shock in an immunocompetent patient. Case report. Case Rep. 2017;3(2):60-9.

36. Peñaa CLS, Tarazona MLA, Alarcónc IE, Dazad MFJ. Paracoccidioidomicosis Una enfermedad multisistémica. Acta Med Colomb. 2018:43(2):111-4.

\section{Publisher's Note}

Springer Nature remains neutral with regard to jurisdictional claims in published maps and institutional affiliations.
Ready to submit your research? Choose BMC and benefit from:

- fast, convenient online submission

- thorough peer review by experienced researchers in your field

- rapid publication on acceptance

- support for research data, including large and complex data types

- gold Open Access which fosters wider collaboration and increased citations

- maximum visibility for your research: over $100 \mathrm{M}$ website views per year

At BMC, research is always in progress.

Learn more biomedcentral.com/submissions 